\title{
Marxian Socio-Political Economic Theory: Two Schools of Thought: Part-II
}

\author{
M. L. Sehgal, PhD \\ D.A.V. College, Jalandhar, Punjab (India)
}

\begin{abstract}
Marx, an idealist, who believed 'Capitalism to be an Evil' and 'Socialism a Harbinger of Prosperity', propagated his economic ideas whose basic Pillar was the Labor Theory of Value (LTV) which included Surplus Value (SV), Falling Tendency of Rate of Profit, Price of a Commodity, Supply and Demand' Relation, Inflation and Interest Rates. His Sociopolitical thought included the state would be the Monopolist without anybody owning any private property with religion being the opiate of the masses. He preached class struggle but ignored the middle class. He wanted to do away the State even with the violent Revolution. All this brought him in conflict both with his contemporary economists as well as with the future generation of economists. The 150 old Socio-political Economic Theory of Marx, though a noble idea, could not stand the test of the times and started falling under its weight. The duality in the minds of the people about its utility and applicability is best described by the celebrated Physicist- Einstein's viewpoint which speaks volumes of the aura of the man named Karl Heinrich Marx:"I am convinced (that) there is only one way to eliminate these grave evils, namely through the establishment of a socialist economy, accompanied by an educational system which would be oriented toward social goals. In such an economy, the means of production are owned by society itself and are utilized in a planned fashion. A 'planned economy', which adjusts production to the needs of the community, would distribute the work to be done among all those able to work and would guarantee a livelihood to every man, woman, and child". But look at the lurking fear in the mind of the genius about the 'planned economy' as: "Nevertheless, it is necessary to remember that a planned economy is not yet socialism. A planned economy as such may be accompanied by the 'complete enslavement of the individual'. The achievement of socialism requires the solution of some extremely difficult socio-political problems: how is it possible, because of the far-reaching 'centralization of political and economic power', to 'prevent bureaucracy from becoming all-powerful and overweening'? How can the 'rights of the individual be protected' and therewith a 'democratic counterweight to the power of bureaucracy be assured'?"
\end{abstract}

Keywords: Labour Theory of value (LTV), Surplus -Value (SV), Falling Tendency of Rate of Profit, Supply and Demand', Inflation, Interest Rates, Socio-political Thought, Monopolist, Private Property, religion being the 
opiate of the masses. Class Struggle, Middle Class; Withering away of State, Violent Revolution.

\section{INTRODUCTION}

On the tomb of Marx in north London (England) are inscribed the words:

The philosophers have only interpreted the world, in various ways. The point, however, is to change it.

Karl Heinrich Marx is not a prophet, although a very good realist and capitalist analyzer. Yes, he was an idealist who propagated an original economic idea in the $19^{\text {th }}$ century in the form of his 'SocioEconomic Theory' to change the Economic way of life of mankind; especially the poor working class. He did succeed, to some reasonable extent. But it is a bitter reality that the economy of any state is interrelated to its politico- historical perspective because Economics is 60\% Science while the rest goes to the prevailing political conditions and the past historical background of the state.

"Moral is everything that serves the cause of Communism"-such as the definition of the Communist morals by Lenin.[1]

Marxism preached a secularized religion. The Statute of the Party stipulated that the member of the Party is liable "to fight resolutely against religious prejudices, petit-bourgeois habits and other manifestations that are alien to Marxism-Leninism".[2] The coming of the 1848 Revolution in France, also known as the 'February Revolution' (révolution de Février) kindled new hope in the minds of Marx and Engel. They convened an international conference in London (1847) in anticipation of a revolution that they believed to be imminent and brought out Communist Manifesto in February 1848.

Marx's theory of 'Class Struggle', which looked quite genuine, was categorically rejected by Mahatma Gandhi as he believed that class war was incompatible with nonviolence. He wrote:

"The idea of class war does not appeal to me. In India, a class war is not inevitable, but it is avoidable if we have understood the message of nonviolence. Those who talk about class war as being inevitable, have not understood the implications of nonviolence or have understood them only skin-deep." [3]

Gandhi welcomed the nonviolent version of Communism though he was against its violent version. He said:

"Communism of the Russian type, that is communism which is imposed on a people, would be repugnant to India. If communism came without any violence, it would be welcome".[4]

\section{METHODOLOGY}

The research material was collected both from the official and non-official agencies. A historical and analytical approach was taken into consideration while using primary and secondary sources. The primary sources are available at the National Archives of India, Delhi, Punjab State Archives, Chandigarh, Punjab State Archives, Patiala, Dwarka Das Library, Chandigarh and The Museum Library, Delhi. The Modern Review, and Asiatic Review. The secondary sources such as the relevant Journals, newspapers, magazines, articles, books especially the three volumes of 'Das Kapital', 'The Communist Manifesto', 'Karl Marx's Theory of Revolution', the frequent use of the internet for the 
Sehgal, M. L. (2020) Marxian Socio-Political Economic Theory: Two Schools Of Thought: Part-II. Advances in Social Sciences Research Journal, 7(5) 452-477. updated material as well as published theses were assessed to present an objective work as far as possible.

\section{Limitations of the Marxian Theory of Economics}

\section{DISCUSSION}

Marxian Theory of Economics suffers from quite a few limitations which will be briefly discussed under the following two main headings:

a. Some Flawed Basic Principles

b. Marx's Highly Individualistic Ideas about Economics

They are briefly discussed as follows:

\section{Some Flawed Basic Principles}

No doubt, we have, already, given a passing reference regarding the three of these basic principles, e.g. Labor Theory of Value (LTV), Theory of Surplus Value (SV) and Falling Tendency of Rate of Profit [5] but these three have been severely criticized by the economists belonging to other schools of thought. Their take on these three principles viz.-a-viz. Marx's views will, now, make an important part of this study

\section{Labor Theory of Value (LTV)}

The three correlated terms which acted as the basis of Marxian socio-political-economic theory are the Labour Theory of Value (LTV), Surplus-value (SV), and Falling Tendency of Rate of Profit. The central idea of three - the (SV) was calculated by Marx by applying the LTV. Later on, he tried to correlate it with the Falling Rate of Profit.

But many economists turned their backs from Marx's principles for calculating the SV. Some, even, opined that it is, rather, an uphill's task to calculate the exact SV.

Since the basis of SV is LTV, it becomes necessary to put forward the opinions of the Economists belonging to the other schools of thought as follows, Marx believed that the value of a good is based on the amount of labor put into it. If one creates a widget by spending 100 hours of labor while another person makes a doohickey with only50 hours' labor, a doohickey, being more useful, has greater demand in the market and has more worth and thus the futility of Marx's argument.

Carl Menger, considered by many to be the founder of the Austrian school, wrote:

"that the economic values of goods and services are subjective in nature, so what is valuable to you may not be valuable to your neighbor".[6]

Marx's theory of value tried to be objective about how much something is worthwhile, the Austrian economists reminded us that value is subjective based on supply and demand.

The LTV is a theory of capitalist production or generalized commodity production. However, there are commodities bought and sold under capitalism that have an 'imaginary' price even though they do not have a value.

a. Some objects that, in themselves, are not commodities, such as conscience, honor, and the like, are capable of being offered for sale by their holders. Hence an object may have a price 
without having a value. The price, in that case, is imaginary. On the other hand, the imaginary price-form may sometimes conceal either a direct or indirect real- value relation as follows: The price of uncultivated land, which is without value, because no human labor has been incorporated in it.[7] The LTV only becomes inapplicable for uncultivated land when that land can never be productive no matter how much commercial labor is expended on it. Desert sand, gibber plains, and icy wastes have very small land values because no commercial labor can be diverted from other uses to be usefully employed.

b. In some cases, the price-form represents the indirect socially necessary labor that could be usefully employed as follow:

1. Pieces of art could be explained as instances of monopoly.

2. Uncultivated land has a price, even if there is no labor involved. The price of land is explained by the theory of rent. Both Ricardo and Marx had developed theories of land-rent based on the LTV.

3. Paper money, according to Marx, "the function of gold as a coin becomes completely independent of the metallic value of that gold. Therefore, things that are without value, such as paper notes, can serve as coins in its place".[8]

4. The value of shares is explained similarly to the value of the land.

c. Marx gave an incoherent distinction between skilled and unskilled labor. The whole of the labor required some degree of skill. So it is not possible to determine the number of unskilled labor hours.[9] Depending upon the type of labor, even an unskilled laborer may become skilled and vice- versa such as the skilled laborer of a school graduate may prove to be unskilled labor while a peasant becomes a skilled person. So it is unclear what should be used as a measure of unskilled labor and which measure would determine skilled labor.[ 10]

d. Joan Robinson though would, appreciate Marx's ideas but was critical of the LTV to name it a "metaphysical doctrine" and "logically a mere rigmarole of words". [11] She wrote:

"Value is something different from price, which accounts for prices, and which in turn has to be accounted for. And to account for it by labor-time is mere assertion... This theory of prices is not a myth... Nor was it intended to be an original contribution to science. It was simply an orthodox dogma".[12]

e. Pilkington believed:

"Value is attributed to objects due to our desire for them. This desire, in turn, is intersubjective. We desire to gain a medal or to capture an enemy flag in battle because it will win recognition in the eyes of our peers. A medal or an enemy flag is not valued for their objective properties, nor are they valued for the amount of labor embodied in them, rather they are desired for the symbolic positions they occupy in the inter-subjective network of desires".[13]

Finally, the following paragraph by Dembinsky may, well, be cited about LTV :

Marxian economies were effectively left with an open and crucial question on how to assess the labor value, which is not answered in Marx's works. Most of them applied an ideologically safe "average labor time" model, which had a however considerable negative influence on effectiveness by "discouraging marginal productivity gains".[14] 
Sehgal, M. L. (2020) Marxian Socio-Political Economic Theory: Two Schools Of Thought: Part-II. Advances in Social Sciences Research Journal, 7(5) 452-477.

\section{Skewed Theory of Surplus Value (SV)}

Since Marx correlates everything with labor put in by the 'working class', his theory of Surplus Value(SV) could not escape from the scrutiny by the watchful eyes of the economists belonging to the other schools of thought. Justice demands that we should also put forward their views, though very briefly, lest we lose sight of the original economic ideas of Marx.[15]

\section{How comes the Word Surplus?}

The first thing is to know as to how the term 'surplus' is defined and understood. [16]

The idea can be simplified into formula $\mathrm{A}-\mathrm{B}=\mathrm{C}$.

We explain this simple-looking equation by taking different examples

i. If A represents the total of commodities produced in a working day and B is the total number of commodities necessary to subsistence, then $\mathrm{C}$ represents the total commodities whose value is surplus-value.

ii. If A represents the total value produced during a standard working day and B the value of a day's subsistence for the worker and then $C$ represents surplus-value.

iii. If A represents the length of the working day in hours and B the number of socially necessary hours required to produce a day's subsistence, then $\mathrm{C}$ represents the hours during which the worker is producing surplus value.

iv. If A represents the total value produced by a day's labor effort and B the value paid back as a wage to the worker, then $\mathrm{C}$ represents the value also produced by labor but appropriated by the capitalist employer.

v. If A represents the standard labor days and B is the portion of this required to produce the worker's subsistence, then $C$ represents the uncompensated portion of the workday.

vi. Finally, if A represents all the values of commodities put into the exchange, then B represents the portion of these commodities that continues to circulate among workers because this much must be paid to them as wages, then $C$ represents the commodities that are drawn out of the exchange process by the capitalist employer who uses them partially for his consumption and partially as further advances (a fund circulating capital) wherewith, he again hires workers to produce more surplus-value

Being 'socially abstract', we cannot treat SV to be equal to net-profit because the net 'profit-type' income is subject to all kinds of fluctuations in S\&D(Sales and Distribution)while SV will be attributable to all sorts of actors and agents, including not only interest-bearing capitals and merchants but possibly even segments of labor itself ( managerial 'labor'). Shaikh and Tomak call 'productive' (value-creating) and 'unproductive' (value-/circulating) labor (not the same as 'useful' vs 'not useful'). In such a case, it would not make any sense to simply add the net profit to Finance and manufacturing together, as the entire financial sector is constituted out of SV.

Thus depending on the angle from which the phenomena are viewed, $C$ may represent the exploited portion of the worker's labor power or the hours during which the worker labors for the capitalist rather than for himself. But Surplus-value is not created by trading transactions. Goods have to be produced before they can be sold, and the producing capitalist would expect to make a profit apart from his trading partner's profit. 
The surplus-value comes from labor-power. The capitalist buys labor power for the money (wages) (M); labor-power becomes labor (products, commodities) (C); commodities are sold (money). So: (M) - M.C.M.

The commodities are sold at their value; not at the cost of production. No capitalist sells goods or services at the cost of producing them as he is not in business merely to receive his money back. So value is determined by the amount of socially useful labor contained in commodities.

Wages represent a certain time in which the worker contracts to work for the employer, whether it be an hourly or weekly rate, or a monthly salary. He must, at some point, is required to produce the value of his wages. So, it becomes necessary for him to labor up to the point where he has, in effect, produced the value of his wages. This is called the necessary labor. But he continues to work beyond this period of necessary labor, i.e. he is, rendering a certain amount of surplus labor. The worker does not own his labor, rather this is the property of the capitalist but it would be hard to separate it from the laborer as it exists in him the form of muscle, brain, and nerve; the human organism. He is, therefore, making a gift to his employer for every second of time he spends in the labor process over and above that is necessary to reproduce the value of his wages, which is the necessary labortime. It is precisely this surplus labor-time that manifests itself in the physical products of labor and, thus, becomes the surplus-value, an additional quantity for which the capitalist has not paid. So the value of labor-power and the value of labor are not the same things.

Surplus $=($ Commodity sell price $)$ - (Previous labour, in used tools, equipment, raw material) - (your labor cost).

Thus it is difficult to measure surplus-value by Marx's definition.

You can probably say that a small shop which sells directly to customers, the profit will before all taxes be the surplus-value, but even in this case, rent is your surplus realized by someone else.

\section{Meghnad Desai and Baron Desai differ with Marx}

According to Marx, surplus-value is equal to the new value created by workers over their labor-cost, which is appropriated by the capitalist as profit when products are sold. It is based on the labor theory of value (LTV) which wrongly holds that value of a created commodity depends on labor only; rather depends on several factors like the cost of production and market forces as explained by Meghnad Desai and Baron Desai. They observed that the surplus value can arise from sources other than labor and site a classic example of winemaking as follows:

When grapes are harvested and crushed, labor is used. However, when yeast is added and the grape juice is left to ferment to get wine, the value of wine exceeds that of the grapes significantly, yet labor contributes nothing to the extra value implying that value and surplus value could come from somewhere other than labor.[17]

Finally, let us hear from the horses' mouth as follows: 
Sehgal, M. L. (2020) Marxian Socio-Political Economic Theory: Two Schools Of Thought: Part-II. Advances in Social Sciences Research Journal, 7(5) 452-477.

\section{LTV and Labor-Time Relation: Something Lacking}

Ideologues like Marx, Engels, and Charles Bettelheim, have favored employing units of labor-time for planning production under socialism. But this is not in conformity with the Marx's labor theory of value (LTV)as it tries to explain the determination of prices under commodity production while Marx says that there can be no 'value' in the post-capitalist society. The LTV, as an explanation of market prices and the labor-time planning proposal, are two distinct theories, which may stand or fall independently. According to Marx's theory, actual prices virtually always diverge from 'values' defined as units of labor-time. If the LTV were the correct explanation of market prices, this, in itself, would not show that units of labor-time and if units of labor-time could effectively be employed, this would not require that the LTV be the correct explanation of market prices.

\section{Value of a Commodity Contains Surplus-Value}

The capitalists do not arbitrarily fix their profits over their cost of production. They sell the goods for what they think the market will stand, but the starting point is what it costs them. It is, however, the secret of commodities that, when brought to the market, they will exchange with other commodities according to the amount of socially necessary labor time contained within them, and no capitalist knows this, and although he will know the amount of time his process has taken. Value contains surplus-value. The fact that articles do not always sell at their Value: sometimes above or below and it does not alter this rule. Buying and selling influence prices but they do not determine them. Profit is not made from trading transactions but the productive process. The surplus product becomes the surplus, i.e. surplus-value is the social fund from which the profits all sections of the capitalist class.

\section{Surplus Value and Falling Tendency of Rate of Profit}

According to the Law of Falling Tendency of Rate of Profit, the profits tend to come down and it plays an important role in the breakdown of the capitalistic economy.

According to Marx, the value of the commodity ( $w$ ) is given by the sum of "constant capital" (c) i.e. expenditure on the plant and machinery used up in production plus the "variable capital" (q) which is paid to labor in the form of wages plus the 'surplus value' (s) which is earned by labor but it is pocketed by the producers.

Suppose the working day consists of 8 hours and only 4 hours are required to produce a commodity. Then in such a case, for the remaining 4 hours, the worker is producing a surplus(s) which is expropriated by capitalists. So, the relation between the four terms may be written as:

$$
\mathbf{w}=\mathbf{c}+\mathbf{q}+\mathbf{s}
$$

If ' $x$ ' is used to represent the rate of surplus-value or the rate of exploitation, it becomes:

$$
\mathbf{x}=\mathbf{s} / \mathbf{q}
$$

Taking into consideration the fact of surplus four hours of work done for the variable capital(q)

$$
\mathrm{x}=\mathrm{s} / \mathrm{q}=4 / 4=100 \%
$$


But the rate of profit ( $\mathrm{p}$ ) in the Marxian model is given as:

$$
p=s /(q+c)
$$

Dividing the numerator and denominator by q, it becomes:

$$
\begin{gathered}
p=\frac{s / q}{q / q+c / q} \\
p=\frac{s / q}{1+c / q}
\end{gathered}
$$

As $x=s / q$ (rate of exploitation) and if $c / q=j$ which Marx calls 'organic composition of capital', then putting them in the above equation:

$$
p=\frac{x}{1+j}
$$

If ' $x$ ' remains constant, there exists an inverse relationship between " $p$ " and " $j "$. As the capitalistic system grows, the amount of organic composition of capital (j) increases. Whenever the wages exceed the subsistence wages, the producers substitute capital for labor to maintain their profits. This situation promotes unemployment.

So if ' $\mathrm{x}=\mathrm{s} / \mathrm{q}$ (rate of exploitation)' should decrease,' $\mathrm{j}$ ' should increase. This can be achieved either by decreasing 'c 'or by increasing ' $q$ '. Now 'c, the initial expenditure' cannot be changed. The choice will be to increase ' $q$ ' which is the sum of wages paid to labor and the 'surplus value' (s) which is earned by labor but is pocketed by producers. If there is a reasonable understanding between the labor and the producer, i.e. labor appreciates that ' $q$, the variable quantity' is also the amount spent by the producer, the chances of conflict between the two classes will diminish.

\section{Marx on Price of Commodity: Labor Class to Decide}

Marx should have given weightage to machines, paper, or even to the capital in addition to the labor.

\section{Marx and Steele Strike Horns}

David Steele believes that perhaps Marx thought that when commodities are exchanged, they must have something in common and that something can be nothing but labor. But 'Capital' could have served an efficient purpose as it could buy the machines and other inputs which meant that it is the capitalist class which produces all the wealth while the other classes; especially the unproductive working-class, contributes no capital. But Marx thought that these salable goods require no labor inputs. Moreover, It would have been an anti-thesis of Marx's thought who believed that the working class is exploited by other classes. Steele thinks that Marx should have thought that labor is just another input in the production process which would nullify the argument that 'capital exploits labor'; rather would change it to saying 'that labor exploits capital or electricity exploits roofing tiles'.[18] Steele called it 'marginal theory'. Indeed, it has been argued that Marx never offered (despite promising to do so in Volume 3 of Capital) a positive proof for his theory. [19] 
Sehgal, M. L. (2020) Marxian Socio-Political Economic Theory: Two Schools Of Thought: Part-II. Advances in Social Sciences Research Journal, 7(5) 452-477.

\section{Economists of Classical and Neoclassical Schools Oppose Marx}

The classical school of economics holds that the objective costs of production determine the price and the neoclassical school holds that prices are determined by the equilibrium of demand and supply.

\section{Austrians Differ Both from Economists of Classical School and Marx}

The Austrian school rejects both these views by saying the costs of production are also determined by subjective factors based on the value of alternative uses of scarce resources, and the equilibrium of demand and supply is also determined by subjective individual preferences. This Austrian school of thought also holds the view that prices are determined by subjective factors like an individual's preference to buy or not to buy a particular good.[20] This school further believes that if any increase in the money supply is not supported by an increase in the production of goods and services, it leads to an increase in prices. But the prices of all goods do not increase simultaneously. Prices of some goods may increase faster than others, leading to greater disparity in the relative prices of goods. For example, Peter, the plumber, may discover that he is earning the same dollars for his work, yet he has to pay more to Paul, the baker when buying the same loaf of bread. [21] If laborers were hired directly as slaves, robots, beasts of burden or servants, then whether or not labor times were the measure of value, surplus labor would not be extracted in the form of money profits but directly, like domestic labor." [22, 23]

But Marx has the answer to this typical situation as follows:

"In the slave system, the money-capital invested in the purchase of labor-power plays the role of the money-form of the fixed capital, which is but gradually replaced as the active period of the slave's life expires". [24]

\section{Albert Einstein makes a point}

Finally, the celebrated Physicist Albert Einstein has rightly said on the LTV "It is important to understand that even in theory, the payment of the worker is not determined by the value of his product".[25]

\section{Marx on Price Control: A Contradiction}

Price controls were one of the main proposals of Marx to "abolish capitalism and lead to the dictatorship of the proletariat" from the State. In the communist manifesto (see: Abolish Private Property), Karl Marx wrote on price:

The price of a commodity, and, therefore, also of labor, is equal to its cost of production.

This economic doctrine is nothing more than an optimum for the masses. Marx, perhaps, was too idealistic because the price of any good is determined by supply and demand. So is the price of labor. It does not look rational to connect the cost of production with a price; i. e. the cost has nothing to do with the price. Following common examples would explain this point further:

i. When one makes some expensive but useless thing, nobody will purchase it at a high price. We take an example of the diamond- water paradox. Diamonds are costly but have no utility or value while water is a necessity for life but is cheap.

ii. Even if there is some useful thing but the customers call it costly given the market conditions and would not buy it and will go for alternative solutions. 
iii. A commodity has a double nature: use-value and exchange-value. The exchange value is determined by its social production cost.

In conclusion, the market does not care what you have paid for something. Also, a person you are trying to sell a stock will not care about your investment cost. In short, if you buy anything, its value is determined by the aggregate demand and aggregate supply. This is marginal economics. The argument that 'Price Fixation' could work is based on the 'false intrinsic theory of value'.

\section{Marx: Different View on 'Supply and Demand' Relation}

Marx believed that when supply and demand balance or become equal to each other, they would cancel each other out. So the equilibrium prices could not be explained. Thus arose the need for the labor theory of value where Marx thought that prices needed to be explained by some third factor, beyond supply and demand.

\section{Steele Differs}

Steele differs from Marx and argues that this misconception on the part of Marx is based on the view that supply and demand are magnitudes or numbers; rather they are schedules or functions.[26] When they become equal, they do not cancel each other out but rather coincide, i.e. at that very price, the quantity supplied is equal to the quantity demand while other prices represent when supply and demand diverge. To be specific, we must bear in mind that the price is determined by supply and demand, even when the two coincide. Again, supply and demand determine price and fluctuations about price but not the cost of value. However, it cannot explain why houses always have many times higher prices than shoes.

\section{Marx: Capitalism is an Evil}

Marx believed Capitalism to be evil as follows:

1. Capitalists desire to accumulate more and more capital. (Law of Capitalistic Accumulation). It gets centralized in a few hands and with the growth of capitalism; the cut-throat competition will develop amongst the capitalists.

2. . The big firms will throw away the small firms, monopolies grow and power concentrates into a few hands (Law of Concentration of Capital).

3. Profits tend to come down and helps in the breakdown of the capitalistic economy ( Law of Falling Tendency of Rate of Profit).

4. Growth of capitalism adds to the miseries and agonies of laboring class by giving subsistence wages which increase the number of unemployed and Marx calls it 'Industrial Reserve Army of Labor' (Law of Increasing Pauperization)

This sharpens the class conflict between capitalists and workers or between 'have' and have-nots'. Eventually, capitalism will face a violent death in the final confrontation when the expropriators will be expropriated.

\section{"The last capitalist we hang shall be the one who sold us the rope." (Quote by Karl Marx)}

Hence, Marx gave the clarion call: 'Workers of the world unite' [27] as they have nothing to lose excepting their 'Chain'.

\section{Capitalist's Viewpoint}

Since it is Capitalist's own money, he would allocate it to where it's most needed as he knows 'either you give people what they are willing to pay for or someone else will'. Socialism is inherently wasteful 
Sehgal, M. L. (2020) Marxian Socio-Political Economic Theory: Two Schools Of Thought: Part-II. Advances in Social Sciences Research Journal, 7(5) 452-477.

[28] as the government is spending someone else's money and is not particularly concerned about losing it. Moreover, political compulsions often trump the effectiveness of a program.

\section{Socialism Failed in many Countries}

The alleged goals of socialism were: the abolition of poverty, the achievement of general prosperity, progress, peace, and human brotherhood. Bu the results have been a failure A perusal of looking at economies of the countries belonging to the socialist world goes as follows:

The demise of the former communist USSR, the unification of East and West Germanys after over four and a half decades, socialist countries like North Vietnams (now North and South Vietnams are united as the Socialist Republic of Vietnam on 2 July 1976), North Koreas (united till the end of WWII in 1945 as Korea), Cuba and Venezuela, etc, is an eye-opener for the Marxists. The list will become longer if we include Poland, Czechoslovakia, Hungry, and Romania. China, being an iron-walled country practicing Maoism, does not fall under the ambit of Communism as initiated by Marx or its liberal face- the Leninism as practiced in Russia after Stalin.[5]

After seeing the plight of the economy of the Socialist world, especially the collapse of the USSR, the socialists coined terms called 'State Capitalism' or 'Crony Capitalism'. But they forget that Capital now includes the money, the labor, the ideas, and the management expertise because it is now free from the rigorous state control of the Socialist world said it well as follows:

"America's abundance was created not by public sacrifices to the common good, but by the productive genius of free men who pursued their interests and the making of their private fortunes. They did not starve the people to pay for America's industrialization. They gave the people better jobs, higher wages, and cheaper goods with every new machine they invented, with every scientific discovery or technological advance and thus the whole country was moving forward and profiting, not suffering, every step of the way"[29].

\section{Contradictions Galore}

1. Many people give a contradictory view that as to why there are still poor people in capitalistic countries. But even poverty has different yard-sticks to be measured. In some parts of the world, poverty means living in a hut with a dirt floor while in America, most poor Americans have all amenities to make their lives livable like having TVs, refrigerators and cell phones.

There is no denying the fact that the rich may take home a larger share of the pie in capitalism, but the poor also benefit in a growing and thriving economy.

2. Capitalism may have its share of limitations, but generally, we will always find the government neck-deep in the economic mess in its PSUs (India) versus most of the important private entrepreneurs

3. As things deteriorate, the state will blame its failure on capitalists promoting more social reform and accelerating the decline toward total control.

\section{Inflation: Marx Prefers Gold Standard over Paper Money}

Karl Marx was opposed to inflation and applied the Labor Theory of Value (LTV) to money to use gold or silver. He said that like all other commodities, there is an amount of "socially necessary labor" required to produce it. If, for example, one ounce of gold requires ten hours' labor, its value is equal to another product requiring ten hours' labor and wrote: 
"Although gold and silver are not by nature money, money is by nature gold and silver.

..."What Marx put forward was that the total value of a needed currency represented a total amount of labor value, and therefore total weight of gold.[30]

Continuing, Marx added if the total of gold is replaced by inconvertible paper money and the paper money is then issued in excess, prices will go up. If the quantity of paper money issued is double, the values previously expressed by the price of $£ 1$ will now be expressed by the price of $£ 2$ (ideally). So he was very critical of the Currency School of Thought and opposed to Peel's Act of 1844 which forbade notes unbacked by metallic money. [31] There being some inconsistency in Marx's thinking regarding inflation as follows:

1. The main difference between Marx and other economists is that Marx was simply trying to describe how capitalism operates, with or without inflation. He was not saying that inflation will improve or destroy capitalism. In Marx's view, capitalism is inevitably unstable and doomed.

2. Marx, though, opposed Peel's Act of 1844, criticizes fiduciary credit as being "fictitious capital" while in Chapter 25 of III volume of Das Kapital, he uses the word real capital for it.

Note: Fictitious capital is a concept used by Karl Marx in his critique of the political economy. It is introduced in chapter 25 of the third volume of Capital. Fictitious capital contrasts with what Marx calls "real capital", which is capital invested in physical means of production and workers, and "money capital", which is actual funds being held

\section{Lenin: Says yes to Marx on Inflation}

Lenin, further, debunked [30] the Currency Money in his article 'The Threatening Catastrophe' [32] as follows:

Everybody recognizes that the issue of paper money is the worstkind of a compulsory loan, that it worsens the conditions principally of the workers, of the poorest section of the population, that it is the chief evil in the financial confusion. ... The unlimited issue of the paper money encourages speculation, allows the capitalists to make millions, and places tremendous obstacles in the path of the much-needed expansion of production; for the dearth of materials, machines, etc., grows and progresses by leaps and bounds. How can matters be improved when the riches acquired by the rich are being concealed?

But the following quote is wrongly attributed to Lenin:

"The best way to destroy the Capitalist System is to debauch the currency."[33]

\section{But Todays' Socialists differ with Marx and Lenin on Inflation and Sound Money}

On the contrary, many socialists nowadays are in favor of inflation, because it is supposed, in Keynes's words, to "euthanize the rentiers." And socialists find themselves hard-pressed to justify why both the stalwarts - Marx and Lenin supported sound money.[30]

\section{Austrian School of Thought on Inflation}

Austrians believe any increase in the 'Money-Supply' not supported by an increase in the production of goods and services, leads to an increase in prices; though prices of all goods do not increase simultaneously. Prices of some goods may increase faster than others, leading to greater disparity in the relative prices of goods. 
Sehgal, M. L. (2020) Marxian Socio-Political Economic Theory: Two Schools Of Thought: Part-II. Advances in Social Sciences Research Journal, 7(5) 452-477.

The reason why the prices of all goods and services do no increase simultaneously lies in the fact that the prices of those goods through which the money is injected into the system adjust before other prices. For example, if the government is injecting money by purchasing corn, the prices of corn would increase before other goods, leaving behind a trail of price distortion.[34]

\section{Austrians' View}

The Austrian school rejects the classical view of capital which says interest rates are determined by supply and demand of capital. The Austrian school holds that interest rates are determined by the subjective decision of individuals to spend money now or in the future. In other words, interest rates are determined by the time preference of borrowers and lenders. For example, an increase in the rate of saving suggests that consumers are putting off present consumption and that more resources (and money) will be available in the future.

\section{Marx's highly individualistic economic ideas}

Marx, being, an original thinker, had initiated many novel ideas in the field of economics which are briefly explained as follows:

\section{State: A Monopolist}

In a Communist Economy, the state is the only owner of the means of production. There is no "Allpeople Ownership"; rather "People" are the employees. But "People" cannot decide what would be produced. Their fate is fully in the hands of the Party which forms a Party Bureaucracy, i.e. a 'new social class' emerges. It is the members of the Presidium of the Central Committee who are neither the proprietors nor can estimate profits or have any responsibility for losses, take the decisions. This fuzzy ownership results in an arbitrary flow of capital. Instead of paying taxes to the state, the factories hand over their share of profit. So the factories do not generate any profit as Communism considers it as a 'social necessity'.

\section{State: Innovations Neglected}

It happens in many ways as follows:

\section{Debts Pile-up}

Slowly these factories start running on the subsidy given the State, i.e. become a burden on the state exchequer. A time comes, when the 'State' starts borrowing. The foreign debts pile-up and for most times are consumed in fulfilling the 'social necessity' as enshrined in the law of Communism propagated by Marxism. All this is done at the cost of innovations in the means of production which causes the decay of infrastructure and technological deterioration. [41]

\section{Lack of Competition}

The capitalist countries would drive more innovation because of their affluence to purchase machinery. They find new ways to attract customers who would, then, purchase their goods among other competitors which, in turn, drives further innovation in an attempt to stay competitive. It is not possible in communist countries where all goods would be equally shared and distributed. So no one would feel the need to compete for customers; leading to stagnation with no need for innovation. Western economist Havel calls it:

\section{"Communist exploitation of the future" [42]}


Note: Some economists opine that the lack of competition may not be treated as the rule of the economics as the two Communist Majors-the Soviet Union and China have made the most rapid economic developments and are fairly at par with the western countries.

\section{Lesser Economic Growth}

With more competition, the Capitalist countries produce considerably more economic growth than their socialist brothers. This produces more jobs, more wealth, and helps everyone.

John Kennedy, once, remarked:

"A rising tide lifts all boats." [43]

Religion is the opium of the people "is one of the most frequently used statements of Karl Marx. It was translated from the German original as follows:

"Die Religion... ist das Opium des Volkes" and is often rendered as "religion... is the opiate of the masses."

In Marx's words:

1. 'Religion is the sigh of the oppressed creature, the sentiment of a heartless world and the soul of soulless conditions. It is the opium of the people.

2. One of the main 'functions' of religion is to prevent people from making demands for social change by dulling the pain of oppression.

3. Religion does not only ameliorate the sufferings of life but it also effectively creates false consciousness.

4. The proletariat suffers deprivations because of their exploitation by the Bourgeois; however, people fail to realize this because religion teaches them that all the miseries in life are God's will.

5. In religion, people make their empirical world into an entity that is only conceived, imagined, that confronts them as something foreign.

6. Religion also acts as a tool of social control in a more direct sense.

According to Marx and Engels:

'The parson has ever gone hand in hand with the landlord'. [44]

\section{No Need of Religion in Communism}

In communism, a person controls the conditions of his labor and lives only 'for himself'. So the religion withers away.

"The foundation of irreligious criticism is: Man makes religion, religion does not make a man. Religion is, indeed, the self-consciousness and self-esteem of man who has either notyet won through to himself, or has already lost himself again. But man is no abstract being squatting outside the world. Man is the world of man - state, society. This state and this society produce religion, which is an inverted consciousness of the world because they are an inverted world.[45]

\section{Evidence to Support Marxism on Religion}

Historically, Marxists have a valid point to argue that religion, many a time, did not play a fair role in society as: 
Sehgal, M. L. (2020) Marxian Socio-Political Economic Theory: Two Schools Of Thought: Part-II. Advances in Social Sciences Research Journal, 7(5) 452-477.

a. The traditional caste system in India was supported by the Hindu religion as it believed in reincarnation.

b. In Medieval Europe, Kings ruled by the 'divine right of God'.

c. Ancient Egyptian believed that Pharaohs were both men and gods at the same time.

\section{Evidence against Marxism on Religion}

Marxism wrongly criticizes religion as evil. It is natural, essential, and a useful social institution and has a history behind it. No one can deny it for some evils but at the same time, no one can accept the thesis that it is harmful as religion would not, always, prevent social change by creating false class consciousness. One can cite many examples where the oppressed groups have used religion to bring about social changes. Of the many, we cite five well- known instances where religion has played a constructive role in bringing about social changes.

a. Max Weber's 'Protestant Ethic and the Spirit of Capitalism' is one of the best-loved accounts of how religion can bring about social change. Weber pointed out that Capitalism developed first in England and Holland, taking off in the early 17th century (the early 1600s). Just before Capitalism, Protestantism was the main religion in these two countries, unlike most other countries in Europe at that time which were Catholic. To cut short, Max Weber argued that the social norms instilled by Protestantism laid the foundations for modern capitalism.

b. Neo-Marxist Otto Maduro cites the example of 'Liberation Theology' in Latin America [46] to prove that religion can act as a force for social change. He, further, suggests that this is especially the case where the marginalized have no other outlet for their grievances than religious institutions.

c. Reverend Martin Luther King(Jr.) and the broader Baptist Church in the Southern United States played a major role in the Civil Rights movement of1960s in America. This movement effectively helped to end racial segregation in America and secure more equal political rights for non-whites.

'I just want to do God's will. And he's allowed me to go to the mountain. And I've looked over, and I've seen the promised land! I may not get there with you, but I want you to know tonight that we as a people will get to the promised land'. [47]

d. Though the USSR, a communist state, placed restrictions on the practice of religion, including banning religious instruction to children, yet, religious belief remained stronger; rather flourished in the 20 $0^{\text {th }}$ century in Russia and Eastern Europe than it did in the capitalist west.[48]

'There must be a religion for women as there must be on for the common people, and the same reason' [49]

e. Religion seems to be more or less universal in all societies as it is considered more useful to fulfill other individual and social needs, possibly in a more positive way as suggested by Functionalist theorists such as Durkheim, Malinowski, and Parsons.[50]

\section{Max Weber: Holds Different View on Religion}

Max Weber (1864-1920), an influential scholar who made a remarkable contribution to sociological theory in the $19^{\text {th }}$ century would hold different views about the religion. Weber says that religion enables individuals to achieve their interests [51] as it a system of social relationships that are 
characterized by belief in supernatural powers revealed through different charismatic manifestations through symbolic expressions by the clergy

\section{Marx: Abolish Private Property}

Communism is not for the abolition of property generally, but the abolition of bourgeois property. So Marx's theory may be understood in this sense and should not be taken it its wordily meaning. Sadly, bourgeois dispossess others by inventing a legal code to justify this robbery which had been going on since the $18^{\text {th }}$ century when the bourgeois would seize of common lands of the laboring poor like in Scotland, the highland clearances removed crofters from the land and turned it into sheep ranges by the use of force. In England, the common land was forcibly snatched and given to big farmers who were provided the legal documents. The same thing happened though out the British Empire while the native inhabitants of North America were deprived of their lands .[52]

Background of the idea of disowning the people of their private property is given as follows:

At the second conference of the Communist League on 29 November 1847 in London, Marx, and Engels won the League over to their ideas. Marx was commissioned to write the League's official program. Marx wrote the 'Communist Manifesto' in late 1847 in Brussels, drawing on Engels's earlier drafts. It was published in mid-February in German in London under the title Manifesto of the Communist Party (Manifest der Kommunistischen Partei) in February 1948

In this manifesto, Marx made a distinction between the property and BOURGEOIS property under the heading: "Property in General' versus 'Bourgeois Property'.The Bourgeois property comes through dispossessing others and then inventing a legal code to justify this robbery. Thus came to the 'Abolition of private property' as enshrined in the 'Communist Manifesto'(Chapter2).[53]

Marx believed that the working class was born from being pushed from the land which made them wage-laborers who 'creates capital, i.e., that kind of property which exploits wage-labor, and which cannot increase except upon condition of begetting a new supply of wage-labor for fresh exploitation'.

\section{Labourer and Entrepreneur: Equal before the Law}

About $85 \%$ of the cost of making a product goes to labor while the labor class is still seeking a larger share of the profits. The right to the fruit of our labor is granted, but this right is not the basic right for the proprietor to own the fruit of property. If our ability to labor, think, or invent is a private possession, i.e., our private property, so should be the fruit of our inventions, labor, or savings in property and the tools of production. The entrepreneur, also, has the right to purchase freely and keep it with him. When a laborer who sells his labor (idea or excellence), obviously an entrepreneur also has the right to keep the tools (invention)/ profit and, thereby, the property acquired with himself. If an individual who sells his labor is free to refuse, so should be the very basis of a free society for the general prosperity for all; be he a laborer or proprietor as enshrined in the equality before the law and equal rights.

\section{Owning Property: A Natural Instinct}

"Nobody spends somebody else's money as carefully as he spends his own. Nobody uses somebody else's resources as carefully as he uses his own. So if you want efficiency and effectiveness, if you want knowledge to be properly utilized, you have to do it through the means of private property." [54] 
Sehgal, M. L. (2020) Marxian Socio-Political Economic Theory: Two Schools Of Thought: Part-II. Advances in Social Sciences Research Journal, 7(5) 452-477.

\section{Marx: Only two Economic Classes; Ignores 'The Middle Class'}

According to Marx, there are only two classes in society- bourgeoisie; who own production, and the proletariat; the class who does not own production but labor for the bourgeoisie.

Marx called the middle class "petty bourgeoisie" or "petty capitalists" because they did not own the means of production. Neither they were a part of the bourgeoisie nor were they common workers and, therefore, they were not truly part of the proletariat. [55] According to Marx, the middle class was comprised of doctors, lawyers, architects, and other professionals as well as small business owners and believed that they tended to aspire to be more bourgeois than proletarians and had more characteristics in common with the bourgeoisie than with the proletariat. Marx, willfully, ignored the middle class because he thought that the successful members of the middle class would become members of the bourgeoisie, while the unsuccessful would be forced into the proletariat. Moreover, Marx believed that the middle class had, at best, a negligible effect on the forces of materialism that shaped the society.

Max Weber holds a different view of the middle class and thinks that this class has many levels. He introduced the middle class as the one class who is socially more active, academically highly argumentative, and being numerically large in number, is more vocal and, thus, has upset Marx's plans for a future proletariat revolution.[56]

Marx could not gauze the strength of the middle class that ultimately, failed Marx and acted as the defenders of the capitalist system. In short, Marx might have made a good analysis of capitalism but he underestimated the role of the middle class.

\section{Marx: Class Struggle Always Existed in Different Forms}

Marx views the class struggle in the historical perspective that had been in existence between the 'haves and have- nots'; though carrying different tags like feudal- lords and vassals, capitalists and workers and proletariat and bourgeoisie ever since the time development of production. According to Marx, the collective interests of these two classes conflict with each other. This happens when the bourgeoisie pays proletariats to make things for them to sell without the proletariats having any say in their wages, work-conditions, and what things they make. But proletariats need the money and, thereby, the jobs. There comes a stage when most of the proletariats get dissatisfied. The division between the two classes is widened. A bulk or all the proletariats unite against the bourgeoisie leading to conflict between the two classes which becomes the 'Class Struggle'[57] and takes the shape of 'Dictatorship of the Proletariat Class' resulting in a 'Communist Society'.

\section{Was Neglecting Middle Class Justified? Marxists should ponder}

Ignoring Middle Class has cost Marx's ideology very dearly. Being academically most literate, it served to protect Capitalism rather than furthering the cause of Class Struggle. With time, many of Marx's assumptions and predictions have become invalid as now the line of demarcation of the bourgeoisie and proletariat is blurred.[57] They may interchange their positions and the hostility between the two classes has, virtually, reached to the extent of extinction. Many modern economists differ on Marx's notion of class as an arbitrary definition which may take the shape of 'Dictatorship of the Proletariat Class' H. J. Laski, one time a staunch follower of Marx, opposes him as follows: [58] 
"The breakdown of capitalism might result not in communism but in anarchy from which there might emerge some dictatorship unrelated in the principle of communist ideals".[58]

\section{Marx: Wants Elimination of State}

Marx's ideas about the state changed three times with time: his early pre-communist phase, the young Marx's phase, and finally in his mature time. Marxism always believed the law as an instrument of coercion designed to protect capitalist ownership of the means of production and to enforce obedience of the oppressed. So the law will no longer be needed in the Communist society, i.e., it will "wither away" and administration would replace "law".[59] He calls every "state is a dictatorship' [60,61] which means every state is imposed by extra-moral, extra-legal force, i.e., is brought about by force and maintained by the force. This is the Marxian way of class dictatorship when he says that the basic units of society and the principal agents of change in human history are social classes, which are defined by their role in human production. Moreover, in every classdivided society, one or more of these classes rules the other classes. There is always a ruling class and one or more subordinate classes (Wikipedia) So Marx's theory of the state now becomes the state is the organizing committee of the ruling class. It is the instrument through which the ruling class coordinates and exercises its rule of the other classes, and, thereby, maintains its status as the ruling class. [62] Through state, the ruling class resolves intra-class conflicts and creates and enforces the rules and policies that ensure their status as the ruling class. That's what the state does, and that's what the state IS.

In a capitalist society, the ruling class is the capitalist class, who own the means of production, and they dominate the proletariat, who own no means of production. So in a capitalist society, the state is the organizing committee of the capitalist class, through which they coordinate their rule.

\section{Marxism Thesis of 'Withering away' of the State after the Revolution}

Marx's final vision is -there will be no state and the only way to cure what ails us is to revolutionize the society, and the only way to do that is for the subordinate classes to take over the state. This way, they exercise their class dictatorship and ultimately eliminate class divisions in society. Once classes are eliminated, there will be no more roles for a state since states are class dictatorships, and will "wither away."

\section{But State did not 'Wither away' (become obsolete)}

On the contrary, we find that what to talk about surviving, the state is continuing to gain power and authority. It happened by two opposing forces; both supporting each other but due to different reasons. [63]

\section{Liberals: Society can be reformed}

Liberalism had, always, been strongly opposed to Marxism as it has a philosophy of reform, Liberals want to reform the state, and, thereby, reform society. Liberals make concessions to the subordinate class/es because the ruling class deems this necessary to preserve its status. On the contrary, Marxists believe that revolution is the panacea for all the ills of society and thus the opposition 
Sehgal, M. L. (2020) Marxian Socio-Political Economic Theory: Two Schools Of Thought: Part-II. Advances in Social Sciences Research Journal, 7(5) 452-477.

Middle Class: Feels Neglected by Socialism

A vast majority of Middle Class which thinks itself to be let down by Socialism comes to the rescue of maintaining the authority of the state.

In conclusion, Marxism gets defeated. The state is not demolished; rather becomes strongercourtesy: Liberalism and Middle class.

\section{Marx: State is 'Class Institution'; an 'Institution of Coercion'}

According to Marx, the state leads to the coercion of the working class by the rich as follows:

Marx thinks that the state serves as an instrument for the rich and the middle-class attempts continually to suppress the working classes or the public for its welfares. Further, Karl Marx believed that most of the political power of the society is controlled by the bourgeois class, and politics is mainly associated with the concepts of the fight for power. The print and digital media are controlled by the bourgeois. They help them to further their interests. Marx, further, insists that politics is mainly a class conflict, and explains that political relations can be renovated into economic ones. In a way, Marxism indicts state as a class institution and describes it as an instrument of force, violence, and exploitation in the hands of the 'Rich'.

Hal Draper (1914-1990), an American socialist associated with the writing of Karl Marx's 'Theory of Revolution' is a 5-volume work (1977-1990) where he defines a state in the following words:

"The state is the institution or complex of institutions which bases itself on the
availability offorcible coercion by special agencies of society to maintain the dominance
of a ruling class, preserve the existing property relations from basic change and keep all
other classes in subjection".[60]

Max Weber: State is a 'Social Institution':

Karl Marx and Friedrich Engels established this theory in the $19^{\text {th }}$ century while its political thought, the 'Communism' saw the light of the day and, to some extent, flourished in the Social World in the early $20^{\text {th }}$ century. So Marx should be prepared to accept the blame of being a determinist and a reductionist because many things in his theory are not related to economics as, he, wittily neglected to include the middle class.

Marx and his associates (excepting Max Weber) could not 'foresee' that after over half a century, the 'State' will turn into a natural social institution; an instrument of welfare and distinctively pro-poor and pro-down-trodden. It will, no longer, remain a weapon of the rich for exploiting the poor. Marxists, also, could not imagine that countries such as Russia will revolt, East and West Germany will reunite, wisdom will dawn on both the North and South Vietnams, and Poland will go in for its lone furlough with a virtual denunciation of communism. The story may not end here. Marx could not anticipate that our society will, thoroughly turn democratic; his anti-thesis, where all will enjoy equal rights.

\section{Marx Wants: A Classless and Stateless Society}

Marx believed that a truly Utopian society must be classless and stateless. Classless Society refers to as a society in which no one is born into a social class, i.e., distinctions of wealth, income, education, culture, or social network might arise but would only be determined by individual 
experience and achievement; though such type of society had never existed before. Marx, also, knew it well that the class struggle, in some of the other forms, was always in existence since the very beginning of mankind. Marx wished to free the lower class from poverty and give the poor a fighting chance Sadly, Marx died much earlier than it was to be put to test by Socialists. Who knows that this Utopian idea of the 'Idealist Marx' "may become a reality if the "True Communism" (its final phase) is achieved. Mankind would love to wait for the coming of 'Classless Society' with no classes and no class conflicts.

\section{How will a Classless Society Work?}

When, in the course of development, class distinctions have disappeared and all production has been concentrated in the hands of a vast association of the whole nation, the public power will lose its political character as the political power is merely the organized power of one class for oppressing another. If the proletariat, during its contest with the bourgeoisie, is compelled by the force of circumstances to organize itself as a class and if employing revolution, it makes itself the ruling class, and, as such, sweeps away by force the old conditions of production, then it will, along with these conditions, have swept away the conditions for the existence of class antagonisms and of classes generally, and will, thereby, have abolished its supremacy as a class. In place of the old bourgeois society, with its classes and class antagonisms, we shall have an association, in which the free development of each is the condition for the free development of all.[64]

\section{Stateless Society}

Engels writes on the stateless aspect as follows:

As soon as there is no longer any social class to be held in subjection, the class rule, and the individual struggle for the existence based upon our present anarchy in production, with the collisions and excesses arising from these, are removed, nothing more remains to be repressed, and a special repressive force, a State, is no longer necessary.[66]

\section{What is Left in State?}

State interference in social relations becomes, in one domain after another, superfluous, and then dies out of itself; the government of persons is replaced by the administration of things, and by the conduct of processes of production.[65]

\section{Theory of Revolution}

Hal Draper wrote Karl Marx's Theory of Revolution in 5-volumes (1977-1990). The idea of the revolution, also, finds a prominent place in the Manifesto of the Communist Party (Manifest der Kommunistischen Partei) written by Marx and Engels at the second conference of the 'Communist League' on 29 November 1947.

Historically, the class struggle, in some form or the other, had been a reality for long. With the onset of the Industrial Revolution, Marx thought that he would see more of working poor rise financially and socially. However, this did not materialize. In the industrial society, the aristocracy was replaced by the bourgeoisie who owned businesses to earn the profit, and the working class was replaced by the proletariat, the people who labored for wages. 
Sehgal, M. L. (2020) Marxian Socio-Political Economic Theory: Two Schools Of Thought: Part-II. Advances in Social Sciences Research Journal, 7(5) 452-477.

\section{Four Reasons for Alienation}

Marx listed four reasons by which the worker is alienated: the product, the act of producing, himself, and others. The main reason being the worker's exploitation by the capitalist whereby he is not able to live as he otherwise naturally would. This was well expressed as follows:

"The proletarians have nothing to lose but their chains. They have a world to win". [66]

Marx believed that in the end, the workers would unite and overthrow the capitalist ruling class. He thought that the bourgeois-capitalist ruling structure would give way to a revolution led by workers who would replace the order with a more fair system and create a more just and equitable society.

"If alienation and exploitation are social problems caused by the nature of the capitalist system, then the solution is to abolish that system and replace it with a better one".[67]

\section{Lenin Proclaims: Even Violent Revolution is Welcome}

The idea of 'Revolution continued to become stronger. Lenin (August-September 1917) picked up the threads of this idea of revolution. He points out:

'that as capitalism is a system of geopolitical rivalry, the armed forces can be used to defend, expand, or destroy territory and those living in it'.[68]

Lenin added that capitalism predisposes the workers to the acceptance of socialism but it does not spontaneously make them conscious socialists. The proletariat of its own can achieve only "tradeunion consciousness". It was necessary to institute "a party of a new type" capable of imbuing the working class with revolutionary consciousness. Keeping this in mind, he conceived of the Party as a highly centralized organization with a core of experienced professional revolutionaries. [69]

Of course, there would, still, be classes in existence and the new state reflects this. He calls the new state, like Marx before him, a "dictatorship" of the working class. So Lenin, the best follower of Marx had also corroborated with 'The Communist Manifesto'. [53] Lenin argued that the workers' state or "dictatorship" is a transitional one which emerges from the struggle of people to change society and to prevent its overthrow by external or internal ruling class violence. The state form is temporary, and having completed its work, withers away because the state is the product of irreconcilable class antagonism; the class basis for the state has disappeared. [68]

Note: During Marx's time, the word 'dictatorship' originated from 'dictatura'. This was the constitutional right of the legally formed republic, in times of emergency, to delegate some decision making to a one-man ruler. Secondly, the meaning is tied to the idea of the delegation of power which was temporary- 6 months maximum- and was limited to military decisions and suspension of laws but not the creation of new ones.[70]

Lenin made another point that after a revolution, a foremost decisive action should be that "the principle of the state", is accompanied by the recognition that a political revolution must have a "social soul" as follows:

Revolution in general - the overthrow of the existing ruling power and the dissolution of the old conditions - is a political act. Without the revolution, however, socialism cannot come about. It requires this political act so far as it needs overthrow and dissolution. But where its organizing activity begins, where its aim and spirit emerge, their socialism throws the political hull away.[71] 
The following paragraph is reproduced after the Manifesto's ten-point program, discussing how "the proletariat will use its political supremacy":

When, in the course of development, class distinctions have disappeared, and all production has been concentrated in the hands of a vast association of the whole nation, the public power will lose its political character. Political power, properly so-called, is merely the organized power of one class for oppressing another. If the proletariat during its contest with the bourgeoisie is compelled, by the force of circumstances, to organize itself as a class; if by using a revolution, it makes itself the ruling class, and, as such, sweeps away by force the old conditions of production, then it will, along with these conditions, have swept away the conditions for the existence of class antagonisms and of classes generally, and will thereby have abolished its supremacy as a class.

In place of the old bourgeois society, with its classes and class antagonisms, we shall have an association, in which the free development of each is the condition for the free development of all. [72] "Abolition of the state" is no longer a slogan; it is and will continue to be, posed as an ultimate aim of the social revolution. During the wave of Revolutions in 1848 in Europe*, Marx became more emphatic and would proclaim "shattering the existing reactionary state and establishing by revolution a new democratic political power". He explained the ultimate aim of Revolutionary Socialism as follows:

"the declaration of the permanence of the revolution, the class dictatorship of the proletariat as the necessary transit point to the abolition of class distinctions generally, to the abolition of all the relations of production on which they rest, to the abolition of all the social relations that correspond to these relations of production, to the revolutionizing of all the ideas that result from these social relations".[73]

Note: But the real French Revolution continued from 5 May 1789 to 9 November $1799 .$.

\section{No Place of Violence: Assert Liberals}

Marxism advocates revolution as the method of securing the desired objectives. Lenin added that such a revolution has to be a violent and bloody revolution. Today's civilized world would not touch this argument even with a pair of tongs as the 'Revolution' which comes into being through violence and maintains itself through force and violence, can neither be enduringly successful nor fully productive. And to Marx's despair, though, such revolutions occurred in various countries such as Russia and China but did not occur in the more industrialized nations of the time, like Britain and Germany. Stalin gave Marxism an authoritarian totalitarian, dictatorial and tyrannical character which ultimately met with demise. China, being an iron walled state, is ruled by Maoism which is not Communism as envisaged by Marx. One could find quite a few instances where human lives and their rights (forget democratic rights) were badly mauled in almost all the Socialist world countries especially in the former USSR, Cambodia, China, and, to some extent, in Poland. In world history, one can find quite a few instances where the tyranny of the ruler was at its worst best. Marxists must remember the 'secret speech'. [74] made at the $20^{\text {th }}$ Congress of the Communist Party of the Soviet Union on 25 February 1956 by Nikita Khrushchev, the General Secretary of the Central Committee of the Communist Party of the Soviet Union and Premier of the then USSR (1958-64) who did de-Stalinization and paved a way for the Sino- Soviet split. 
Sehgal, M. L. (2020) Marxian Socio-Political Economic Theory: Two Schools Of Thought: Part-II. Advances in Social Sciences Research Journal, 7(5) 452-477.

Still Another instance: in Czechoslovakia when in the Parliament of democratic Czechoslovakia ( 1929), the deputy Zemínová had protested against the speech of the Communist deputy Klement Gottwald, in which he was declaiming that Communists wage war against the State and that they deliberately violate the laws, he replied with arrogance".[75]

"... we harass you and will harass you until we hurl you down. Our revolutionary headquarters is Moscow. And we frequent Moscow to learn how to wring your neck.And you know that Bolsheviks are masters of it."

Following limitations also acted as a deterrent to such a Revolution:

a. Pure laissez-faire capitalism nowhere exists on the earth.

b. Some historians argue that US President Franklin Delano Roosevelt (1933-45) saved capitalism from the ferment developing in the depression of the 1930s.

c. Many of the proposals of the Communist Manifesto have been adopted by capitalist countries.

\section{CONCLUSION}

There are quite a few Marxian views that did not stand the test of the $20^{\text {th }}-21^{\text {st }}$ centuries. The basic pillar of Marx's 'Socio-political Economic Theory' being the 'Labor Theory of Value ( LTV)', read in concurrence with Surplus - Value and Falling Tendency of Rate of Profit, has borne the brunt of attack both from Marx's contemporaries and the future generations of the economists who vehemently opposed his viewpoint on LTV. Marx's love for the Labor Class-the Proletariat and his contempt for the Bourgeois (Capitalism is an Evil) which makes the very basis of his theory has cost him dearly as he placed all his eggs in one basket- the Labor class. So much so, he would proclaim from the rooftop that the price of a commodity should be calculated based on 'the labor' put in and need not be given any weightage to the capital put in for establishing a production unit. What to talk of ignoring the need of the capital, the celebrated social economist paid scant respect to the basic principle of economics that the prices of commodities may vary with the demand and supply. Had Marx given some weightage to the machines, paper, or to the capital in addition to the labor, things would have been different. He was so much obsessed with the welfare of the working class that he, rather intentionally, ignored the most vocal, highly enlightened, and most populous class of the society- the Middle class by calling it 'the Petty Bourgeois'.This class felt neglected by Socialism. Marx might have made a good analysis of capitalism but, perhaps, he underestimated the power of the middle class 'who did not allow Marx to wither away the state; rather it came to the rescue of maintaining the authority of the state; stood in the way of Communism and Revolution and above all acted as a defender of the capitalist system. Marx's idea that State is a 'Class Institution' and it needs to be 'annihilated' did not find favor both with politicians and intellectuals of the different generations. His oft-repeated rant that "religion... is the opiate of the masses." was expected to meet a stiff opposition; rather it recoiled on him as an overwhelmingly large majority of the population of this world (excluding the socialist countries) believed in some god or the other of their own. Marx's idea of doing away with private property, also, did not find favor with the people because owning property is a natural instinct. Even Marx's theory of 'Class Struggle', which looked quite genuine, was categorically rejected by Mahatma Gandhi [3] who, also, voiced against the violent version of Communism. [4]

\section{References}

1. On Communist Morality", in 'The Red Phoenix' 25 December 2011

2. Ldislav Kováč (2002), "Natural history of Communism," Central Europ. Polit. Sci. Rev. 3, 111-164 
3. Gandhi's writing in the English Daily Amrita Bazar Patrika on 2-3August1934

4. M.K.Gandhi, Harijan,13-2-37, p. 6

5. Sehgal, M. L. (2020). Marxism, Communism, Marxian Socio-political Economic Theory and the Socialist World: Part-I. Advances in Social Sciences Research Journal, 7(5) 70-90

6. Carl Menger (1871). "Principles of Economics" published in English in 1950 by OCLC

7. Capital Volume 1, Chapter 3, section 1

8. Capital, Vol 1, Part 1, Section-2

9. Zitzan, Jonathan, and Shimshon Bichler 2009), “Capital power: A study of order and creorder”, Routledge,p.96

10. Nitzan, Jonathan, and Shimshon Bichler (2009), “Capital as Power: A Study of order and creorder,” Routledge, 2009, pp.142-143

11. Joan Robinson, "Economic Philosophy"p.39

12. Joan Robinson,"Economic Philosophy" p.38

13. Philip Pilkington, Marx, Hegel, “The Labour Theory of Value and Human Desire”, 'Econinterest.com', 17 January 2019

14. Dembinsky, Pawel H. (1991), "The Logic of the Planned Economy”, Oxford: Claredon Press

15. Anwar.m. Shaikh \&E.Ahmet Tonak, "Measuring the Wealth of Nations", The Political Economy of National Accounts', 28 November 1996

16. Zera, "Theory of Surplus -Value as a Formula- Economic Theories", 'History of Economic Theory and Thought', 26 April 2020.

17. Desai, Meghnad(2002), “Marx's Revenge: The Resurgence of Capitalism and the Death of Statist Socialism”, 2002, Verso Books, p. 264

18. Steele, David Ramsay (September 1999), "From Marx to Mises: Post Capitalist Society and the Challenge of Economic Calculation," Open Court. p. 144.

19. Donald Ernsberger, Jarret Wollstein (12 October 1988), "The Labour Theory of Value( analysis)", Liberty International, 12 October 1988

20. Includes names like Carl Menger, Ludwig von Mises, Eugen von Bohm- Bawerk, Friedrich Hayek

21. Ibid

22. Greeman, Alan (!996),"Price, value, and profit: a continuous, general treatment,” In Alan Freeman, Guglielmo Carchedi (editors): Marx and non-equilibrium economics. Edward Elgar. Cheltenham, UK, Brookfield, US

23. For the difference between wage workers and working animals or slaves confer- John R. Bell (2009), "Capitalism and the Dialectic - The Uno-Sekine Approach to Marxian Political Economy, p. 45. London, Pluto Press

24. Karl Marx Capital, volume II, chapter XX

25. Albert Einstein, “Why Socialism? Originally published in 1949 in Monthly Review

26. Steele, David Ramsay (1992), "From Marx to Mises: Post Capitalist Society and the Challenge of Economic Calculation", Amazon

27. The last line of the Communist Manifesto Originally was "Working men of all countries, unite!" It was eventually modified into "Workers of the world, unite!" primarily because it just sounds better and there's no potential for people to interpret it in any sexist way

28. John Hawkins, “7 Reasons Socialism Will Make You Poorer Than Capitalism,” Rightwing News, December 2012

29. Ayn Rand and Nathaniel Branden (1966), “Capitalism: The Unknown Ideal" Ayn Rand Institute (ARI) 
Sehgal, M. L. (2020) Marxian Socio-Political Economic Theory: Two Schools Of Thought: Part-II. Advances in Social Sciences Research Journal, 7(5) 452-477.

30. Louis Rouanet, "Lenin and Marx: Sound Money Advocates"? Mises Daily Articles, 7 September 2015

31. The Bank Charter Act 1844 ( 7 \& 8 Vict. c. 32), sometimes referred to as the Peel Banking Act of 1844, was an Act of the Parliament of the United Kingdom, passed under the government of Robert Peel, which restricted the powers of British banks and gave exclusive note-issuing powers to the central Bank of England

32. 'The Impending Catastrophe and How to Combat It', Published at the end of October 1917 in pamphlet form by Priboi Publishers. Source: Lenin Collected Works, Progress Publishers, 1977, Moscow Volume 25, pp.32369,Translated:D. Walters \& C. Farrel

33. Hans Hellwig (1967), Lenin also Inflationspopanz. Das Profil (Munich), April. Quoted by: Frank W. Fetter, "Lenin, Keynes, and Inflation," Economica (1977). It is Ludwig von Mises himself who called Frank W. Fetter's attention to this article written by Hellwig.

34. Keynes's cost-push and demand-pull inflation theory, 'Tech featured', 9 September 2018

35. The Free Library- Business and Industry -Economic Inquiry: I July 1999

36. Keynes 's letter in 'The 31 December 1933 issue of 'the New York Times' [Times, p. 2XX]

37. Capital Vol. III Part V Division of Profit into Interest and Profit of Enterprise. Interest-Bearing Capital Chapter 22, Division of Profit. Rate of Interest. Natural Rate of Interest

38. Tabb,2010

39. Doepke \& Zilibotti, 2008

40. Adam Smith: "Classical Theory," 1.1,20. Interest Rates

41. Kornai, J. (1997), “Communism to the market economy./ (In Slovak) Kalligram, Bratislava,p.75

42. Havel, V. (1991) Letní přemítání. /Summer reflections./ Odeon, Prague

43. John F. Kennedy first used it in the 1950s to describe local economic development projects in New England

44. Communist Manifesto, p. 45

45. Quote by Marx

46. Karl Thomson, "The Neo-Marxist Perspective on Religion”, ReviseSociology,16 July 2018

47. Quote by Martin Luther King (Jr.)

48. Simone de Beauvoir, "Religion and the Second Sex”, 'Revise Sociology', 20 July 2018

49. Simone de Beauvoir, The Second Sex, 1949

50. Karl Thomson, “The Functionalist Perspective on Religion: Summary Revision Notes”, 'Revise Sociology', 13 July 2018

51. Goldstein 115-151

52. John Westmoreland, "Marx's Justification of Abolition of Private Property", 'Counterfire'.13 March 2019

53. 'Property In General Vs. Bourgeois Property" thus came to the 'Abolition of private property' as enshrined in the 'Communist Manifesto (Chapter2)

54. John Hawkins-,"7 Reasons Socialism Will Make You Poorer Than Capitalism", by 4 December 2012

55. Maximilian Karl Emil Weber (21 April 1864-14June 1920) was a German sociologist, philosopher, jurist, and political economist. He is one of the most important theorists in the development of modern Western society. His ideas profoundly influenced social theory and social research. Weber is often cited, with Emile Durkheim and Karl Marx as among the three founders of sociology

56. "Marx and Weber's Ideas of Class, Power, and Capitalism", Free Thesis Papers (online) 28 December 2019

57. Eddie McCabe," Karl Marx's Theory of Class Struggle: The Working Class \& Revolution", 'Socialistic Alternative', May 5, 2018

URL: http://dx.doi.org/10.14738/assrj.75.8280 
58. Harold Joseph Laski (30 June 1893 - 24 March 1950) was an English political theorist and economist. He was active in politics and served as the chairman of the British Labour Party from 1945-1946, and was a professor at the London School of Economics from 1926 to 1950

59. Norman P. Barry(!989)," An Introduction to Modern Political Theory," Amazon, p. 53

60. Hal Draper," Karl Marx's Theory of Revolution, Vol. III: The Dictatorship of the Proletariat, Monthly Review Press, 1977

61. Poder Obrero, "Marx on State, Proletarian Dictatorship and the Commune" 'Revolution',14 November 2017

62. Gbarmes14," Marx's Theory of the state", 'Policy of Truth',16 October 2014

63. For the documents and references, see Hal Draper's article "Marx and the dictatorship of the proletariat", in 'Études de Marxologie' (Paris), No.6, September 1962,pp.38-41.

64. Reproduced from Chapter II of 'The Communist Manifesto'

65. Reproduced from Socialism: Utopian and Scientific

66. "The Communist Manifesto", Fredrick Engels and Marx

67. Phil Gasper, “Capitalism and alienation”, ISR (International Socialist Review), issue: 74: Critical Thinking

68. Paul Vernell, “Classic tests: a Summary of Lenin’s State and Revolution ${ }_{\llcorner}{ }^{\prime C}$ ounterfire', 15 August 2015

69. Vladimir Lenin - "What is to be done"?, 'Communist Party, Social Democracy',23 July 2008

70. Hal Draper-Karl Marx's 'Theory of Revolution', Vol. 3

71. Critical Notes on' The King of Prussia and Social Reform 'in Writings of the Young Marx on Philosophy and Society', (Ed.) Easton \&Guddat, Indiana polis, Ind. : Hackett Pub. Co.,1997, p.357

72. In ME: SW1:54. (Marx and Engels: Selected Works)

73. In ME: SW1:223. (Marx and Engels: Selected Works)

74. Summary of Secret Speech with the main points is given as : (i).Repudiation of Stalin's cult of personality (ii) Quotations from the classics of Marxism- Lenin which denounced the "cult of an individual", especially Karl Marx's to a German worker that stated his antipathy toward it. (iii). Lenin's Testament and remarks by Nadezhda Krupskaya (former People's Commissar for Education and wife of Lenin), about Stalin's character. (iii).Before Stalin, the fight with Trotskyism was purely ideological; Stalin introduced the notion of the "enemy of the people" to be used as "heavy artillery" from the late 1920s .(iv). Stalin violated the party norms of collective leadership. (v). Repression of the majority of Old Bolsheviks and delegates of the XVII Congress most of whom were workers and had joined the party before 1920. Of the 1,966 delegates, 1,108 were declared "counter-revolutionaries"; 848 were executed, and 98 of 139 members and candidates to the Central Committee were declared "enemy of the people".(vi).After the repression, Stalin ceased even to consider the opinion of the collective of the party. (vii). Examples of repression of some notable Bolsheviks were presented in detail. (viii).Stalin's order for the persecution to be enhanced: the NKVD was "four years late" in crushing the opposition, according to his principle of "aggravation of class struggle". The practice of falsifications followed to cope with "plans" for numbers of enemies to be uncovered. (ix).Exaggerations of Stalin's role in the Great Patriotic War (World War II). Deportation of whole nationalities. (x). Doctors' plot and Mingrelian Affair. (xi) Manifestations of personality cult: songs, city names, and so on..(xi). Lyrics of the Late Anthem of the Soviet Union State (first version, 1944-1953), which had references to Stalin. (xii).The non-awarding of the Lenin State Prize since 1935, which should be corrected at once by the Supreme Soviet and the Council of Ministers. (xiii).Repudiating the socialist realist literary policy under Stalin, also known as Zhdanovism, which affected the literary works

75. See a transcription of the speech, Gottwald 1954 